\title{
Optimasi Pertumbuhan dan Multiplikasi Lini Klon PLBs Anggrek Spathoglottis plicata Blume melalui Modifikasi Komposisi Medium MS dan Sitokinin
}

\author{
Optimization of Growth and Multiplication of PLBs Orchid Clone Line Spathoglottis plicata Blume \\ through Modification on MS Medium and Cytokinin
}

\author{
Atra Romeida $^{1^{*}}$, Surjono Hadi Sutjahjo ${ }^{2}$, Agus Purwito², Dewi Sukma ${ }^{2}$, dan Rustikawati ${ }^{1}$ \\ Diterima 12 Oktober 2011/Disetujui 21 Agustus 2012
}

\begin{abstract}
In order to enhance the multiplication of Protocorm Like Bodies (PLBS) of Spathoglottis plicata orchid in vitro, several combinations of vitamin, sucrose concentration, and cytokinin were tested. This experiment was arranged in Completely Randomized Design (CRD) with two factors. The first factor was combination of vitamin composition and sugar concentrations in the medium which consisted of four different combinations $\left(\mathrm{J} 1=\right.$ vitamin $M S+$ sucrose $30 \mathrm{~g} \mathrm{~L}^{-1}, \mathrm{~J} 2=$ vitamin $B 5+$ sucrose $30 \mathrm{~g} \mathrm{~L}^{-1}, \mathrm{~J} 3=$ vitamin $M S+$ sucrose $40 \mathrm{~g} \mathrm{~L} \mathrm{~L}^{-1}, \mathrm{~J} 4=$ vitamin $B 5+$ sucrose $\left.40 \mathrm{~g} \mathrm{L^{-1 }}\right)$. The second factor was seven combinations of cytokinin types and its concentrations $(S O=$ without cytokinin (control), $S 1=20 \mu M$ $B A, S 2=40 \mu M B A, S 3=20 \mu M$ kinetin, $S 4=40 \mu M$ kinetin, $S 5=75 \mathrm{ml} \mathrm{L}^{-1}$ coconut milk, and S6 = $150 \mathrm{ml} L^{-1}$ coconut milk). PLBs were used as explant and were grown on MS solid medium containing various vitamin, sucrose, and cytokinin combinations as mentioned above. Growth and multiplication of PLBs were based on the number of PLBs per explant, number of plantlets per explant, number of roots formed, plantlet height and visual appearance and performance of the observations at 6 MST. The best growth and multiplication of PLBs orchid $\underline{S}$. plicata was produced on MS medium modified with B5 vitamins and $30 \mathrm{~g} \mathrm{~L}^{-1}$ sucrose, followed by those and on MS medium enriched with $75 \mathrm{ml} \mathrm{L}{ }^{-1}$ coconut milk and on MS medium supported by $20 \mu M B A$.
\end{abstract}

Key words : B5, benzyl adenine, coconut water, in vitro,orchid, sugar concentration, vitamin composition

\begin{abstract}
ABSTRAK
Percobaan ini bertujuan untuk mendapatkan formulasi komposisi vitamin dan konsentrasi gula medium, serta jenis dan konsentrasi sitokinin terbaik dalam menginduksi pertumbuhan dan multiplikasi lini klon PLBs anggrek Spathoglottis plicata dalam jumlah yang besar secara in vitro. Percobaan ini menggunakan Rancangan Acak Lengkap (RAL) Faktorial. Eksplan yang digunakan adalah PLBs yang ditanam pada medium Murashige dan Skoog (MS) yang telah dilakukan modifikasi sesuai dengan perlakuan. Faktor pertama adalah formulasi komposisi vitamin dan konsentrasi gula yang terdiri dari empat macam formulasi yaitu $\mathrm{J} 1=$ vitamin $\mathrm{MS}+$ gula $30 \mathrm{~g} \mathrm{~L}^{-1}, \mathrm{~J} 2=$ vitamin $\mathrm{B} 5+$ gula $30 \mathrm{~g} \mathrm{~L}^{-1}, \mathrm{~J} 3=$ vitamin $\mathrm{MS}+$ gula $40 \mathrm{~g} \mathrm{~L}^{-1}, \mathrm{~J} 4=$ vitamin $\mathrm{B} 5+$ gula $40 \mathrm{~g} \mathrm{~L}^{-1}$. Faktor kedua adalah penambahan sitokinin ( 3 jenis dengan 2 taraf konsentrasi) yang terdiri dari 7 kombinasi perlakuan yaitu S0 = tanpa sitokinin (kontrol), S1 = BA $20 \mu \mathrm{M}, \mathrm{S} 2=\mathrm{BA} 40 \mu \mathrm{M}, \mathrm{S} 3=$ kinetin $20 \mu \mathrm{M}$, S4 = kinetin $40 \mu \mathrm{M}$, $\mathrm{S} 5=$ air kelapa $75 \mathrm{ml} \mathrm{L}^{-1}$, dan S6 = air kelapa $150 \mathrm{ml} \mathrm{L}^{-1}$. Pertumbuhan dan multiplikasi PLBs anggrek S. plicata terbaik dihasilkan pada medium MS dengan modifikasi vitamin B5 dan konsentrasi gula $30 \mathrm{~g} \mathrm{~L}^{-1}$ dan pada medium MS dengan penambahan air kelapa $75 \mathrm{ml} \mathrm{L}^{-1}$ serta pada medium MS dengan penambahan BA $20 \mu \mathrm{M}$ dengan kriteria jumlah PLBs akhir dan jumlah planlet akhir tertinggi, jumlah akar dan tinggi tanaman serta penampilan visual hasil pengamatan pada 6 minggu setelah tanam.
\end{abstract}

Kata kunci : air kelapa, anggrek, B5, benzyl adenin, in vitro, komposisi vitamin, konsentrasi gula

\footnotetext{
${ }^{1}$ Fakultas Pertanian Universitas Bengkulu. Jalan Raya Kandang Limun Bengkulu, E-mail: atrapbt@yahoo.co.id (*Penulis korespondensi)

${ }^{2}$ Departemen Agronomi dan Hortikultura Fakultas Pertanian Institut Pertanian Bogor. Telp. 0251-8629353
} 


\section{PENDAHULUAN}

Anggrek Spathoglottis plicata Blume. merupakan salah satu jenis anggrek tanah (terresterial) yang banyak terdapat di Bengkulu dan dapat tumbuh pada tempat-tempat yang marginal dan kurang subur (Romeida, 2008). Namun keberadaan anggrek ini masih belum begitu diminati, karena warna bunganya yang sangat terbatas (putih, merah muda dan ungu cerah), tergantung tempat tumbuhnya. Selain itu, anggrek $S$. plicata masih memiliki kelemahan antara lain mekar bunga yang tidak bersamaan, bunga cepat layu, penampilan tanaman yang kurang proporsional karena memiliki daun yang sangat besar dibandingkan dengan bunganya yang berukuran kecil, tangkai bunga yang terlalu panjang sehingga mudah rebah dan bunganya berukuran kecil.

Saat ini anggrek $S$. plicata banyak digunakan sebagai ornamen taman dan sebagai tanaman hias pembatas jalan sehingga sangat potensial untuk dikembangkan. BALITHI Segunung mulai tahun 2007 sudah melepas tiga varietas baru hasil persilangan yaitu Spathoglottis var. Kartika, var. Bintang Segunung dan var. Ani Bambang Yudhoyono (Kartikaningrum et al., 2007).

Biji anggrek tidak mempunyai endosperma sehingga untuk perkecambahan bijinya tidak perlu ditabur diatas medium in vitro yang mengandung nutrisi dan zat pengatur tumbuh yang sesuai dengan jenis anggrek yang dikultur (Romeida, 2012). Penggunaan zat pengatur tumbuh sitokinin alami maupun sintetik untuk memacu multiplikasi dan pertumbuhan tunas mikro sudah digunakan secara luas pada berbagai jenis tanaman, namun jenis dan konsentrasinya berbeda-beda untuk berbagai jenis tanaman. Penggunaan sitokinin juga sangat penting untuk perbanyakan in vitro berbagai jenis anggrek termasuk anggrek $S$. plicata. Sitokinin merupakan zat pengatur tumbuh yang sangat berperan dalam proses proliferasi sel (Ramirez-Parra, 2005), menginduksi pembelahan sel serta pembentukan dan perkembangan tunas (Mok, 1994), mengaktifkan pucuk tunas lateral yang dorman (Napoli et al., 1999) serta memperlambat senescence (Gan dan Amasino, 1995). Umumnya anggrek sudah dapat tumbuh baik tanpa penambahan sitokinin pada medium tanamnya. Namun dengan penambahan sitokinin dapat memacu multiplikasi (Protocorm Like Bodies (PLBs) dan planlet menjadi lebih cepat.

Multiplikasi PLBs dan planlet anggrek Dendrobium cv. Thampomas tercepat dan tertinggi didapat pada Media MS dengan penambahan 3 ppm BAP (Romeida, 2004), anggrek Dendrobium silangan (cv. Thampomas X cv. Jaq. Hawaii) pada media MS dan Media Knudson $\mathrm{C}$ dengan penambahan $2 \%$ arang aktif dan 5 ppm BAP (Romeida dan Hidayanti, 2005). Jumlah planlet terbanyak anggrek Dendrobium Chao Praya Smile dihasilkan pada medium MS dengan penambahan 4.4 $\mu$ M BA (Hee et al., 2009). Pembentukan embrio somatik sekunder dan perkembangannya menjadi planlet kopi Arabika dihasilkan pada medium dengan penambahan $0.6 \mu \mathrm{M}$ IAA dan $22.2 \mu \mathrm{M}$ BAP (Oktavia et al., 2003).

Seeni dan Latha (1992) melaporkan bahwa regenerasi eksplan daun anggrek Red Vanda (Rhenanthera imschootiana) pada medium Mitra et al. (1976) dengan penambahan $44.4 \mu \mathrm{M}$ BA, $17.7 \mu \mathrm{M}$ NAA, $2 \mathrm{~g} \mathrm{~L}^{-1}$ sukrosa dan $2 \mathrm{~g} \mathrm{~L}^{-1}$ pepton menghasilkan kalus mulai dari 10 sampai 12 minggu setelah tanam (MST). Kalus membentuk PLBs terjadi pada medium yang diperkaya dengan $10 \%$ air kelapa dan $35 \mathrm{~g} \mathrm{~L}^{-1}$ bubur buah pisang setelah 12 minggu kemudian. PLBs yang berkembang menjadi tunas baru terjadi setelah 12 minggu berikutnya lagi. Modifikasi pada medium untuk anggrek Red Vanda (Seeni dan Latha, 1992) dengan meningkatkan konsentrasi air kelapa menjadi $15 \%$ dapat menghasilkan jumlah tunas tertinggi pada anggrek Blue Vanda (Seeni dan Latha, 2000).

Penggunaan medium MS dengan modifikasi medium menggunakan B5 telah dilakukan untuk meningkatkan multiplikasi dan ketegaran tanaman sebelum diaklimatisasi. Penggunaan medium $1 / 2 \mathrm{MS}$ dengan penambahan 60-90 $\mathrm{g} \mathrm{L}^{-1}$ sukrosa mampu mempertahankan pertumbuhan optimum Lili kultivar Avignon dan Bergamo, tanpa menyebabkan pertumbuhan abnormal selama percobaan in vitro (Kenyo et al., 2002). Rimpang mikro jahe Gajah dapat pula distimulasi dengan pemberian $4.61 \mathrm{ppm}$ BAP dan $30 \mathrm{~g} \mathrm{~L}^{-1}$ sukrosa (Marlin, 2005) dan penggunaan $30 \mathrm{~g} \mathrm{~L}^{-1}$ sorbitol dapat meningkatkan proliferasi tunas dan akar, mampu meningkatkan bobot basah akar pada batang bawah peach G 677 (Ahmad et al., 2007)

Penelitian ini bertujuan untuk mendapatkan formulasi komposisi vitamin dan konsentrasi gula yang paling tepat pada medium in vitro untuk mendukung pertumbuhan dan perkembangan planlet anggrek S. Plicata. Penelitian ini juga bertujuan untuk mendapatkan jenis dan konsentrasi sitokinin terbaik dalam memproduksi pertumbuhan dan multiplikasi PLBs dan planlet lini klon anggrek $S$. plicata dalam jumlah besar secara in vitro dan mengevaluasi pengaruh interaksi kedua faktor perlakuan dalam mempengaruhi pertumbuhan dan perkembangan planlet anggrek $S$. plicata sampai 6 MST. 


\section{BAHAN DAN METODE}

Bahan tanam yang digunakan adalah lini klon PLBs anggrek S. plicata yang dihasilkan dari multiplikasi satu biji anggrek yang dikultur pada médium MS selama 6 MST.

Percobaan ini menggunakan Rancangan Acak Lengkap (RAL) yang disusun secara faktorial. Faktor pertama adalah komposisi vitamin dan konsentrasi gula yang terdiri dari empat macam komposisi yaitu $\mathrm{J} 1=$ vitamin $\mathrm{MS}+$ gula $30 \mathrm{~g} \mathrm{~L}^{-1}, \mathrm{~J} 2$ = vitamin $\mathrm{B} 5$ + gula $30 \mathrm{~g} \mathrm{~L}^{-1}, \mathrm{~J} 3=$ vitamin $\mathrm{MS}+$ gula $40 \mathrm{~g} \mathrm{~L}^{-1}, \mathrm{~J} 4=$ vitamin $\mathrm{B} 5$ + gula $40 \mathrm{~g} \mathrm{~L}^{-1}$. Faktor kedua adalah penambahan sitokinin (3 jenis dengan 2 taraf konsentrasi) yang terdiri dari 7 kombinasi perlakuan yaitu $\mathrm{S} 0=$ tanpa sitokinin (kontrol), $\mathrm{S} 1=$ BA $20 \mu \mathrm{M}, \mathrm{S} 2=\mathrm{BA} 40 \mu \mathrm{M}, \mathrm{S} 3=$ kinetin $20 \mu \mathrm{M}$, $\mathrm{S} 4=$ kinetin $40 \mu \mathrm{M}$, S5 = air kelapa $75 \mathrm{ml} \mathrm{L}^{-1}$, dan $\mathrm{S} 6$ = air kelapa $150 \mathrm{ml} \mathrm{L}^{-1}$. Setiap kombinasi perlakuan diulang sebanyak lima kali (5 botol kultur). Medium dasar yang digunakan dalam percobaan ini adalah medium Murashige dan Skoog (MS) yang telah dimodifikasi sesuai dengan perlakuan. Setiap botol kultur diisi medium sebanyak $20 \mathrm{ml} \mathrm{botol}^{-1}$, selanjutnya diinkubasi selama 1 minggu untuk mengetahui apakah medium benarbenar sudah steril. Medium yang steril selanjutnya ditanam dengan 10 PLBs yang sudah memanjang, tapi belum berkembang sempurna membentuk planlet dengan ukuran antara $0.5-1.0 \mathrm{~cm}$.

Pengamatan karakter kualitatif seperti warna planlet, warna daun, dilakukan secara visual setiap minggu. Sedangkan karakter pertumbuhan (kuantitatif) yang diamati setiap minggu meliputi jumlah anakan, tinggi tanaman, jumlah daun dan jumlah akar. Pengamatan tinggi planlet dilakukan pada akhir percobaan atau pada saat sub kultur.
Uji-F pada karakter kuantitatif dilakukan untuk mengetahui adanya perbedaan antar perlakuan yang diberikan. Bila terdapat beda nyata antar perlakuan dilanjutkan dengan Duncan Multiple Range Test (DMRT). Data kualitatif dibuat tabulasi dan ditampilkan secara visual menggunakan foto.

\section{HASIL DAN PEMBAHASAN}

Uji F tidak menunjukkan perbedaan antar perlakuan. Modifikasi komposisi medium tanam dengan mengubah komposisi vitamin dan konsentrasi gula yang terdapat di dalam medium MS berpengaruh nyata terhadap jumlah PLBs akhir (multiplikasi PLBs), jumlah planlet, jumlah daun, jumlah akar dan tinggi planlet pada 6 MST. Modifikasi formulasi vitamin B5 dengan konsentrasi gula $30 \mathrm{~g} \mathrm{~L}^{-1}$ merupakan kombinasi terbaik dalam multiplikasi PLBs anggrek S. plicata (Tabel 1). Kombinasi perlakuan tersebut mampu menghasilkan multiplikasi tertinggi dan berbeda nyata dengan ketiga kombinasi perlakuan lainnya dengan kriteria jumlah PLBs akhir terbanyak yaitu 31 PLBs baru per eksplan. Jumlah PLBs yang berkembang menjadi planlet juga sangat tinggi yaitu 13.1 planlet per eksplan dengan jumlah daun mencapai 4.4 helai per planlet. Kedua karakter pertumbuhan vegetatif tersebut merupakan indikator dari taraf multiplikasi yang sangat penting dalam produksi benih masal. Karakter jumlah akar terbanyak yaitu 2.8 buah per planlet dan tinggi planlet tertinggi yaitu $6.8 \mathrm{~cm}$ dihasilkan pada modifikasi Vitamin B5 dengan peningkatan konsentrasi gula medium MS menjadi $40 \mathrm{~g} \mathrm{~L}^{-1}$

Tabel 1. Pengaruh formulasi komposisi vitamin dan konsentrasi gula medium terhadap pertumbuhan PLBs anggrek S. plicata pada 6 MST

\begin{tabular}{|c|c|c|c|c|c|}
\hline \multirow{2}{*}{$\begin{array}{l}\text { Komposisi vitamin dan } \\
\text { konsentrasi gula }\end{array}$} & \multicolumn{5}{|c|}{ Peubah yang diamati pada $6 \mathrm{MST}$} \\
\hline & $\begin{array}{c}\text { JPLB } \\
\left(\text { PLBs eksplan }^{-1}\right)\end{array}$ & $\begin{array}{c}\text { JPLT } \\
\text { (planlet eksplan }^{-1} \text { ) }\end{array}$ & $\begin{array}{c}\text { JD } \\
\text { (buah plt }^{-1} \text { ) }\end{array}$ & $\begin{array}{c}\text { JA } \\
\text { (buah plt+-1) }\end{array}$ & $\begin{array}{l}\mathrm{TT} \\
(\mathrm{cm})\end{array}$ \\
\hline $\mathbf{J 1}\left(\right.$ Vitamin $\mathrm{MS}+$ gula $\left.30 \mathrm{~g} \mathrm{~L}^{-1}\right)$ & $19.2 \mathrm{~b}$ & $4.3 \mathrm{~b}$ & $3.5 \mathrm{a}$ & $2.1 \mathrm{ab}$ & $2.7 \mathrm{c}$ \\
\hline $\mathbf{J 2}\left(\right.$ Vitamin B5 + gula $\left.30 \mathrm{~g} \mathrm{~L}^{-1}\right)$ & $31.0 \mathrm{a}$ & $13.1 \mathrm{a}$ & $4.4 \mathrm{a}$ & $1.7 \mathrm{ab}$ & $4.1 \mathrm{bc}$ \\
\hline $\mathbf{J 3}\left(\right.$ Vitamin MS + gula $\left.40 \mathrm{~g} \mathrm{~L}^{-1}\right)$ & $10.0 \mathrm{c}$ & $2.0 \mathrm{c}$ & $3.9 \mathrm{a}$ & $1.1 \mathrm{~b}$ & $3.0 \mathrm{bc}$ \\
\hline $\mathbf{J 4}\left(\right.$ Vitamin $\mathrm{B} 5+$ gula $\left.40 \mathrm{~g} \mathrm{~L}^{-1}\right)$ & $10.8 \mathrm{c}$ & $2.5 \mathrm{c}$ & $3.7 \mathrm{a}$ & $2.8 \mathrm{a}$ & $6.8 \mathrm{a}$ \\
\hline
\end{tabular}

Keterangan: Angka-angka yang diikuti oleh huruf yang sama pada kolom yang sama tidak berbeda nyata pada DMRT taraf $\alpha=5 \%$; JPLB = jumlah PLB; JPLT = jumlah planlet; JD = jumlah daun; $\mathrm{JA}=$ jumlah akar; $\mathrm{TT}=$ tinggi tanaman

Perbedaan formulasi komposisi vitamin medium juga memberikan pengaruh yang berbeda terhadap karakter yang diamati. Penggunaan vitamin B5 lebih baik dibandingkan dengan vitamin MS (standar) dalam multiplikasi PLBs guna menghasilkan PLBs baru dalam jumlah besar. Jumlah PLBs akhir rata-rata yang dihasilkan mencapai 


\section{J. Hort. Indonesia 4(1):1-8. April 2013.}

41.8 PLBs per eksplan setelah 6 MST. Komposisi vitamin B5 mengandung konsentrasi beberapa senyawa organik yang lebih tinggi bila dibandingkan dengan komposisi vitamin MS. Perbandingan konsentrasi vitamin B5 (Gamborg B-5 medium) dengan vitamin MS adalah konsentrasi Nicotinic acid $2 \mathrm{x}$ lebih tinggi, Thiamin- $\mathrm{HCl} 20 \mathrm{x}$ lebih tinggi, dan Pyridoxine-HCl 10 x lebih tinggi. Namun ada kelebihan vitamin MS yaitu mengandung asam amino Glycine dengan konsentrasi $2 \mathrm{ml} \mathrm{L}^{-1}$ sementara vitamin B5 tidak terdapat Glycine (Gamborg, 2002). Beberapa tanaman seperti wortel sangat membutuhkan asam amino sebagai sumber $\mathrm{NH}^{2-}$ sebagai nitogen tereduksi yang berfungsi sebagai buffer yang mampu menjaga kestabilan $\mathrm{pH}$ medium terutama dalam menginduksi pembentukan embrio somatiknya (Ramage dan Williams, 2002; Dahleen dan Bregitzer, 2002). Namun untuk anggrek ternyata ada atau tidaknya glycine tidak terlalu berpengaruh terhadap pertumbuhan dan multiplikasi PLBs.

Kecepatan multiplikasi PLBs anggrek $S$. plicata sangat penting dalam produksi lini klon guna menghasilkan bahan tanam yang seragam. Sementara untuk jumlah planlet akhir, jumlah daun, jumlah akar dan tinggi planlet berdasarkan DMRT 5\% tidak menunjukkan hasil yang berbeda nyata. Modifikasi vitamin dan konsentrasi gula juga berpengaruh terhadap penampilan PLBs $S$. plicata (Gambar 1).

Perbedaan kombinasi jenis dan konsentrasi sitokinin di dalam medium MS (7 kombinasi perlakuan) yang digunakan sebagai medium tanam percobaan multiplikasi PLBs anggrek $S$. plicata berpengaruh nyata terhadap jumlah PLBs akhir (multiplikasi PLBs), jumlah planlet, jumlah daun, jumlah akar dan tinggi planlet pada 6 MST. Konsentrasi gula $30 \mathrm{~g} \mathrm{~L}^{-1}$ merupakan konsentrasi terbaik untuk multiplikasi PLBs karena mampu menghasilkan jumlah PLBs akhir tertinggi (25.1 PLBs PLB $^{-1}$ ) dan jumlah PLBs yang mampu berkembang menjadi planlet (8.7 planlet $\mathrm{PLBs}^{-1}$ ) (Tabel 1).

Peningkatan konsentrasi gula pada medium menyebabkan menurunnya pembentukan PLBs (Gambar 1). Konsentrasi gula yang terlalu tinggi dapat menyebabkan medium menjadi terlalu pekat sehingga potensial air dalam medium menjadi lebih rendah dibandingkan potensial air dalam sel dan memacu terjadinya plasmolisis (Marlin, 2005). Sebaliknya, konsentrasi gula yang cukup tinggi diperlukan untuk memacu tinggi planlet, karena gula berperan sebagai sumber energi dalam metabolisme sel. Konsentrasi gula $40 \mathrm{~g} \mathrm{~L}^{-1}$ menghasilkan tinggi planlet tertinggi dibandingkan dengan perlakuan lainnya. Kebutuhan energi diserap oleh PLBs dari medium tanam selanjutnya akan dirombak dalam proses glikolis dan siklus sel guna mendapatkan energi yang sangat dibutuhkan untuk pembelahan dan diferensiasi sel. Gula juga akan dirubah menjadi selulosa akan menjadi komponen utama penyusun dinding sel. Tanaman tidak melakukan fotosintesis selama berada di dalam botol kultur, oleh karena itu kebutuhan gula dipenuhi dari penyerapan langsung melalui medium tanam.

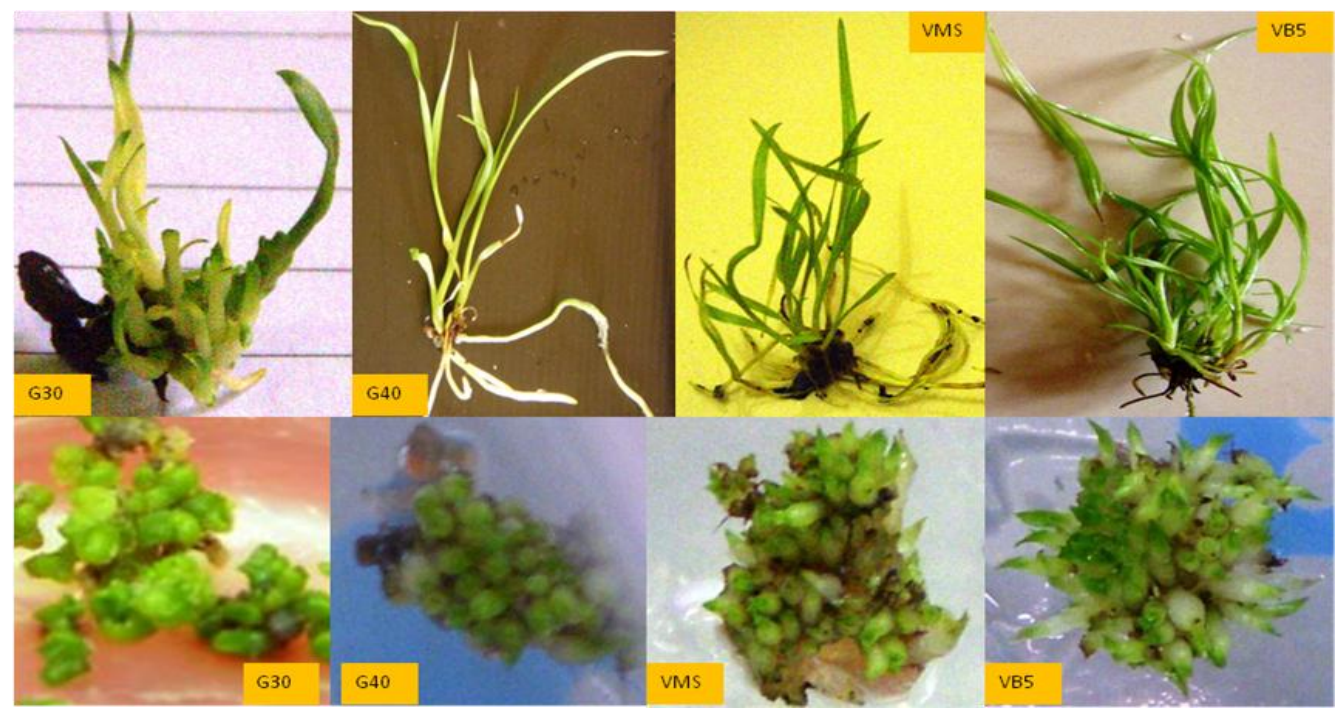

Gambar 1. Penampilan pengaruh modifikasi vitamin MS dan konsentrasi gula terhadap pertumbuhan dan multiplikasi PLB pada 6 MST, VMS = vitamin MS, VB5 = vitamin B5, G30 = gula $30 \mathrm{~g} \mathrm{~L}^{-1}, \mathrm{G} 40=$ gula $40 \mathrm{~g} \mathrm{~L}^{-1}$ 
Perbedaan kombinasi jenis dan konsentrasi sitokinin di dalam medium MS (7 kombinasi perlakuan) yang digunakan sebagai medium tanam percobaan multiplikasi PLBs anggrek $S$. plicata berpengaruh nyata terhadap jumlah PLBs akhir (multiplikasi PLBs), jumlah planlet, jumlah daun, jumlah akar dan tinggi planlet pada 6 MST. Tidak terdapat pengaruh interaksi yang nyata kedua faktor perlakuan yaitu antara komposisi medium (formulasi vitamin dan gula) dengan sitokinin (jenis dan konsentrasinya) terhadap semua karakter pertumbuhan dan multiplikasi PLBs anggrek S. plicata pada 6 MST.

Hasil percobaan ini menunjukkan bahwa medium MS dengan penambahan air kelapa $75 \mathrm{ml} \mathrm{L}^{-1}$ sangat baik untuk memacu pertumbuhan dan multiplikasi PLBs dengan kriteria tingginya jumlah PLB akhir yang terbentuk. Jumlah PLB akhir yang terbentuk tidak berbeda nyata dengan perlakuan peningkatan konsentrasi air kelapa menjadi $150 \mathrm{ml} \mathrm{L}^{-1}$ (9.6 PLBs per eksplan) sama dengan jumlah PLBs yang terbentuk pada medium MS dengan penambahan BA 20 $\mu \mathrm{M}$ (9.6 PLBs per eksplan) setelah 6 MST (Tabel 2). Baiknya pertumbuhan dan multiplikasi PLBs menggunakan air kelapa diduga karena anggrek lebih menyukai sitokinin alami. Komposisi air kelapa lebih kompleks dibandingkan dengan sitokinin sintetik seperti BA dan kinetin. Disamping mengandung zeatin, air kelapa juga mengandung diphenyl urea, gula dan beberapa senyawa organik lainnya (MederosMolina, 2004). Jumlah planlet terbanyak dihasilkan pada medium MS dengan penambahan BA $20 \mu \mathrm{M}$ (6.4 planlet per eksplan) dan medium MS dengan penambahan air kelapa $75 \mathrm{ml} \mathrm{L}^{-1}$ (5.9 planlet per eksplan). Jumlah planlet yang dihasilkan 2-3 kali lipat dibandingkan dengan perlakuan lainnya dalam meninduksi pertumbuhan dan multiplikasi PLBs (Tabel 2).

Berbeda dengan jumlah PLBs dan jumlah planlet akhir yang terbentuk pada $6 \mathrm{MST}$, perbedaan jenis dan konsentrasi sitokinin tidak berpengaruh nyata terhadap jumlah akar dan jumlah daun, karena rata-rata jumlah akar dan jumlah daun yang terbentuk sama dengan kontrol, bahkan dengan pemberian kinetin $20 \mu \mathrm{M}$, pembentukan akar justru semakin berkurang walaupun tidak berbeda nyata dengan kontrol dan paling sedikit yaitu 0.4 buah per planlet (Tabel 2). Jumlah akar yang terbentuk tidak dipengaruhi perlakuan sitokinin karena sitokinin berfungsi memacu pembelahan sel dan multiplikasi tunas namun bukan untuk perakaran. Secara alami sitokinin di dalam tumbuhan diproduksi pada ujung meristem akar dan ditranslokasi secara acropetal menuju ujung pucuk, selanjutnya berfungsi dalam pembelahan sel pada meristem pucuk atau ujung batang (Moore, 1979). Penggunaan sitokinin lebih tepat bila arah dan tujuan penelitian adalah untuk multiplikasi tunas bukan ke arah induksi dan perkembangan perakaran.

Bila dibandingkan ketiga jenis sitokinin yang diberikan pada medium tanam anggrek S. Plicata yaitu BA, kinetin dan air kelapa, terlihat bahwa untuk induksi pertumbuhan dan multiplikasi PLBs sebaiknya mengunakan air kelapa, karena kecepatan multiplikasi PLBs menjadi 2 kali lipat dibandingkan dengan kontrol, yaitu dari rata-rata 5 PLBs per eksplan pada kontrol menjadi 10.3 PLBs per eksplan dengan penambahan air kelapa ke dalam medium tanam (Gambar 2). Penambahan air kelapa kedalam medium tanam dapat memacu perkembangan PLBs menjadi planlet dan tinggi tanaman dengan pengaruh yang sama baiknya dengan pemberian BA $20 \mu \mathrm{M}$. Perbedaan jenis sitokinin tidak berpengaruh terhadap pembentukan akar, seperti umumnya perbanyakan dengan teknik in vitro, untuk memacu pertumbuhan akar sebaiknya menggunakan auksin saja. Penambahan air kelapa ke dalam medium tanam anggrek sangat menguntungkan karena air kelapa mudah didapat dan harganya murah, sehingga sangat menguntungkan untuk perbanyakan anggrek dalam skala komersial.

Tabel 2. Pengaruh jenis dan konsentrasi sitokinin terhadap pertumbuhan planlet S. plicata pada 6 MST

\begin{tabular}{|c|c|c|c|c|c|}
\hline \multirow[b]{2}{*}{ Jenis dan konsentrasi sitokinin } & \multicolumn{5}{|c|}{ Peubah yang diamati pada 6 MST } \\
\hline & $\begin{array}{c}\text { JPLB } \\
\left(\text { PLBs eksplan }^{-1}\right)\end{array}$ & $\begin{array}{c}\text { JPLT } \\
\text { (planlet eksplan }^{-1} \text { ) }\end{array}$ & $\begin{array}{c}\text { JD } \\
\text { (buah planlet }^{-1} \text { ) }\end{array}$ & $\begin{array}{c}\text { JA } \\
\text { (buah planlet }^{-1} \text { ) }\end{array}$ & $\begin{array}{c}\mathrm{TT} \\
(\mathrm{cm})\end{array}$ \\
\hline S0 (Kontrol/tanpa sitokinin) & $5.0 \mathrm{bc}$ & $2.4 \mathrm{bc}$ & $4.0 \mathrm{a}$ & $1.9 \mathrm{~b}$ & $3.71 \mathrm{ab}$ \\
\hline S1 (BA $20 \mu \mathrm{M})$ & $9.6 \mathrm{ab}$ & $6.4 \mathrm{a}$ & $3.9 \mathrm{a}$ & $2.3 \mathrm{a}$ & $3.92 \mathrm{ab}$ \\
\hline $\mathrm{S} 2(\mathrm{BA} 40 \mu \mathrm{M})$ & $3.6 \mathrm{c}$ & $2.8 \mathrm{bc}$ & $4.5 \mathrm{a}$ & $2.2 \mathrm{a}$ & $2.90 \mathrm{~b}$ \\
\hline $\mathrm{S} 3$ (Kinetin $20 \mu \mathrm{M}$ ) & $6.8 \mathrm{~b}$ & $1.5 \mathrm{c}$ & $4.4 \mathrm{a}$ & $0.4 \mathrm{a}$ & $4.72 \mathrm{a}$ \\
\hline $\mathrm{S} 4$ (Kinetin $40 \mu \mathrm{M})$ & $4.2 \mathrm{bc}$ & $3.7 \mathrm{bc}$ & $3.7 \mathrm{a}$ & $2.6 \mathrm{a}$ & $4.68 \mathrm{a}$ \\
\hline S5 (Air Kelapa $75 \mathrm{ml} \mathrm{L}^{-1}$ ) & $11.0 \mathrm{a}$ & $5.9 \mathrm{a}$ & $3.0 \mathrm{a}$ & $1.5 \mathrm{a}$ & $5.75 \mathrm{a}$ \\
\hline S6 (Air Kelapa $150 \mathrm{ml} \mathrm{L}^{-1}$ ) & $9.6 \mathrm{ab}$ & $2.7 \mathrm{bc}$ & $3.6 \mathrm{a}$ & $2.4 \mathrm{a}$ & $4.11 \mathrm{ab}$ \\
\hline
\end{tabular}

Keterangan: Angka-angka yang diikuti oleh huruf yang sama pada kolom yang sama tidak berbeda nyata pada DMRT taraf $\alpha=5 \%$; JPLB = jumlah PLB; JPLT = jumlah planlet; JD = jumlah daun; JA = jumlah akar; TT = tinggi tanaman 


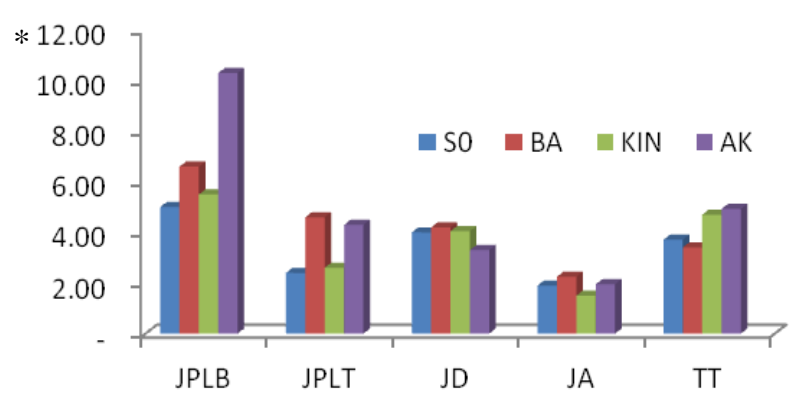

Gambar 2. Pengaruh Jenis Sitokinin terhadap Multiplikasi PLBs Anggrek S. plicata pada 6 MST; *JPLB $=$ jumlah PLB akhir per eksplan $\left(\right.$ PLBs eksplan $\left.{ }^{-1}\right)$ JPLT $=$ jumlah planlet per eksplan $\left(\right.$ planlet eksplan $\left.{ }^{-1}\right) ; \mathrm{JD}=$ jumlah daun per planlet (helai planlet $\left.{ }^{-1}\right) ; \mathrm{JA}=$ jumlah akar per planlet $\left(\right.$ buah planlet $\left.{ }^{-1}\right) ; \quad \mathrm{TT}=$ tinggi tanaman $(\mathrm{cm}) ; \mathrm{S} 0=$ tanpa sitokinin, Kin = kinetin, $\mathrm{BA}=\mathrm{BAP}$, $\mathrm{AK}=$ air kelapa

Hasil penelitian juga menunjukkan bahwa penggunaan kinetin kurang baik untuk multiplikasi PLBs anggrek S. plicata karena jumlah akhir PLBs, planlet, dan tinggi tanaman yang dihasilkan jauh lebih rendah dibandingkan dengan pemberian BA dan air kelapa. Penampilan visual hasil percobaan pengaruh penambahan beberapa jenis dan konsentrasi sitokinin ke dalam medium MS disajikan pada Gambar 3.
Jumlah PLBs akhir, jumlah planlet dan jumlah daun yang banyak, warna daun yang hijau tua dan akar yang kuat dihasilkan pada medium MS dengan penambahan air kelapa. Sedangkan akar yang besar, kuat dengan bulu akar yang sangat banyak dihasilkan pada medium MS dengan penambahan BA. Planlet dengan kriteria yang demikian sangat dibutuhkan karena akan dapat beradaptasi dengan baik pada medium non aseptik setelah dilakukan aklimatisasi.

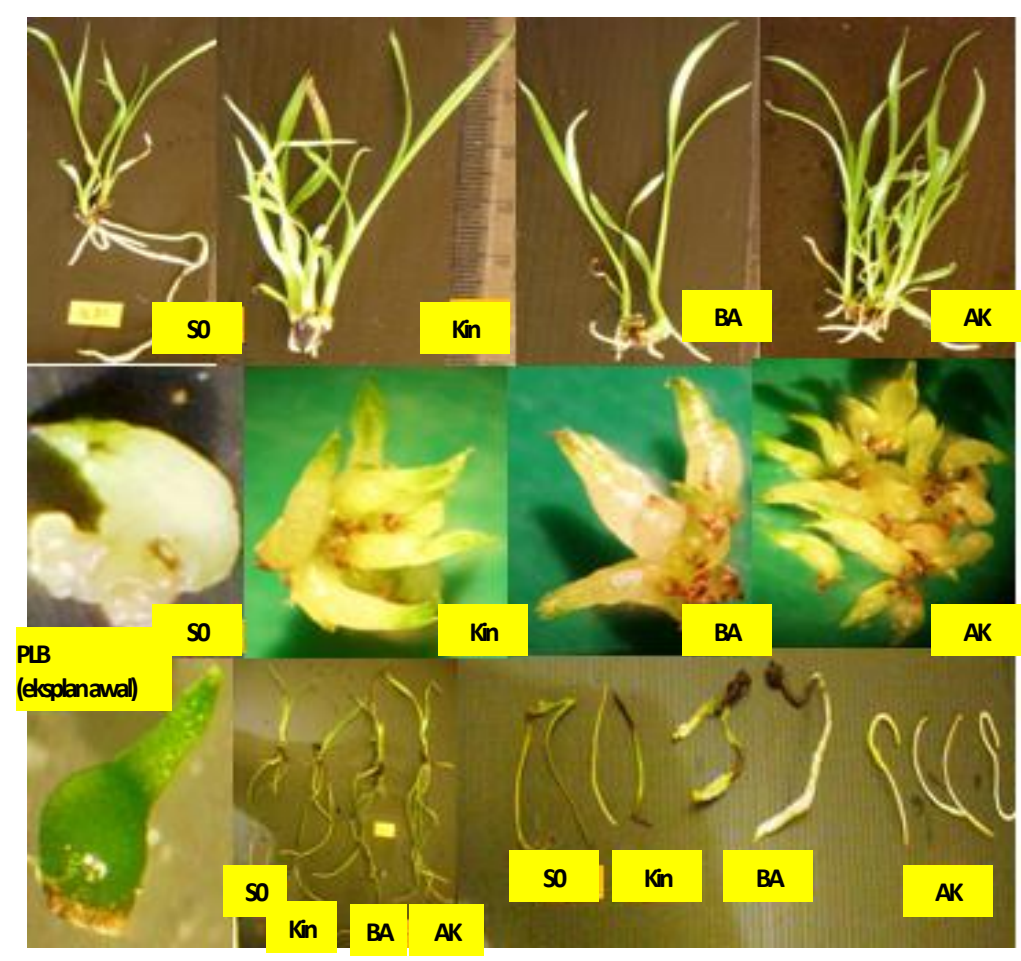

Gambar 3. Penampilan pengaruh jenis dan konsentrasi sitokinin terhadap penampilan PLBs dan planlet pada $6 \mathrm{MST} ; \mathrm{S} 0=$ tanpa sitokinin, $\mathrm{Kin}=$ kinetin, $\mathrm{BA}=\mathrm{BAP}, \mathrm{AK}=$ air kelapa 
Pembengkakan pangkal batang yang selanjutnya diikuti dengan keluarnya fenol dengan jumlah yang cukup banyak (memenuhi permukaan medium dan medium berubah warna menjadi coklat kehitaman) pada medium tanam hanya dijumpai pada perlakuan medium MS + vitamin B5 + 40 $\mathrm{g} \mathrm{L}^{-1}$ gula dan medium MS + vitamin $\mathrm{MS}+150 \mathrm{ml} \mathrm{L}^{-1}$ air kelapa. Planlet dengan pangkal batang yang membengkak diduga akan dapat diarahkan untuk menginduksi pembungaan secara in vitro, karena ciri-ciri tunas yang demikian merupakan fase awal dari pembentukan bunga secara in vitro pada anggrek Dendrobium. Sejalan dengan hasil penelitian yang telah dilaporkan oleh Hee et al. (2009) pada anggrek Dendrobium Chao Praya Smile, Tee et al. (2008) pada anggrek Dendrobium Sonia-17, dan Sim et al. (2008) pada anggrek Dendrobium Madame Thong-In. Ketiga peneliti tersebut melaporkan bahwa induksi pembungaan pada ketiga jenis anggrek Dendrobium yang berbeda memiliki ciri-ciri dan tahapan yang sama, yaitu diawali dengan pembengkakan pangkal batang, tidak terbentuk akar, selanjutnya terjadi pemanjang ruas batang (bolting), muncul tangkai bunga (influorescent) dan terakhir akan terbentuk bunga fluorescent secara in vitro.

\section{KESIMPULAN}

Berdasarkan kriteria jumlah PLB akhir dan jumlah planlet akhir tertinggi, jumlah akar dan tinggi tanaman serta penampilan visual hasil pengamatan pada 6 MST, pertumbuhan dan multiplikasi PLB anggrek $S$. plicata terbaik dihasilkan pada medium MS dengan modifikasi vitamin B5 dan konsentrasi gula $30 \mathrm{~g} \mathrm{~L}^{-1}$ dan pada medium $\mathrm{MS}$ dengan penambahan air kelapa $75 \mathrm{ml} \mathrm{L}^{-1}$ atau dengan penambahan BA $20 \mu \mathrm{M}$ pada medium MS.

\section{UCAPAN TERIMA KASIH}

Terima kasih penulis ucapkan kepada Direktorat Jenderal Pendidikan Tinggi, Departemen Pendidikan Nasional melalui Penelitian Hibah Bersaing tahun I yang telah membiayai penelitian ini melalui dana DIPA Dit Litabmas nomor 0541/0234.1.01/00/2011 tanggal 20 Desember 2010 berdasarkan surat perjanjian nomor 026/SP2H/PL/ Dit.Litabmas/IV/2011 tanggal 14 April 2011.

\section{DAFTAR PUSTAKA}

Ahmad T.A., N.A. Abbasi, I.A. Hafiz, A. Ali. 2007. Comparison of sucrose and sorbitol as main carbon energy sources in micropropagation of Peach rootstock GF-677. Pak. J. Bot. 39(4):1269-1275

Dahleen, L.S., P. Bregitzer. 2002. An improved media system for high regeneration rates from barley immature embryo-derived callus cultures of commercial cultivars. Crop Sci. 42:934-938.

Gamborg, O.L. 2002 Plant tissue culture. Biotechnology. Milestones. In Vitro Cellular Devel. Biol.-Plant. 38: 84-92.

Gan, S., R.M. Amasino. 1995. Inhibition of leaf senescence by autoregulated production of cytokinin. Science. 270:1986-1988.

Hee, K.H., C.S. Loh, H.H. Yeoh. 2009. Early in vitro flowering and seed production in culture in Dendrobium Chao Praya Smile (Orchidase). Plant Cell Rep. 26:2055-2062.

Kartikaningrum, S, Y. Sulyo, N.Q. Hayati, Suryanah, Y.A. Bety. 2007. Keragaan karakter kualitatif hasil persilangan anggrek Spathoglottis. J. Hort. Edisi Khusus (2):138147.

Kenyo, A., H.K. Murdaningsih, T. Herawati, J.S. Darsa. 2002. Tanggap dua kultivar Lili terhadap kombinasi komposisi medium MS dan gula pasir untuk konservasi in vitro. Zuriat. 13(2):87-96.

Marlin. 2005. Pembentukan rimpang mikro jahe (Zingiber officinale Rosc.) secara in vitro dengan pemberian Benzyl Amino Purine dan sukrosa. J. Akta Agrosia 8(2):70-73.

Mederos-Molina, S. 2004. In vitro callus induction and plants from stem and petiole explants of Salvia canariensis L. Plant Tissue Cult. 14(2):167-172.

Mitra, G.C., R.N. Prasad, A. Roychowdhury. 1976. Inorganic salts and differentiation of protocorms in seed callus of orchid and correlative changes in its free aminoacid content. Indian J. Exp. Biol. 14: 350-351. 


\section{J. Hort. Indonesia 4(1):1-8. April 2013.}

Mok, M.C. 1994. Cytokinin : chemistry, activity and function. In Cytokinin and Plant Development an Overview (ed. M. Mok DWS, MC). p.155-156. CRC. Boca Raton, FL.

Moore, T.C. 1979. Biochemistry and Physiology of Plant Hormones. Springer-Verlag New York.

Napoli, C.A., C.A. Beveridge, K.C. Snowden. 1999. Reevaluating concept of apical dominance and the control of axilarry bud outgrowth. Curr. Top. Dev. Biol. 44:127-169.

Oktavia, F., Siswanto, A. Budiani, Sudarsono. 2003. Embriogenesis somatik langsung dan regenerasi planlet kopi arabika (Coffea arabica) dari berbagai eksplan. Menara Perkebunan 71(2) : 44-45.

Ramage, C.M., R.R. Williams. 2002. Mineral nutrition and plant morphogenesis. In Vitro Cellular Devel. Biol. Plant. 38: 116-124.

Ramirez-Parra, E., B. Desvoyes, C. Gutierrez. 2005. Balance between cell division and differentiation during plant development. Int. J. Dev. Biol. 49:467-477.

Romeida, A. 2004. Aklimatisasi Anggrek Silangan Dendrobium cv. Thampomas $\mathrm{x}$ cv. Taq. Hawaii pada Beberapa Taraf Konsentrasi Pupuk Daun Bioplasma dan Jenis Media Tanam. Laporan Penelitian (tidak dipublikasi).

Romeida, A. 2008. Konservasi Anggrek Spesies Endemik Propinsi Bengkulu Secara Ex Situ: Identifikasi Anggrek Spesies di Kabupaten Kepahiang Bengkulu. Laporan Hasil Penelitian Hibah Unggulan UNIB Tahun Anggaran 2007-2008.
Romeida, A. 2012. Induksi mutasi dengan iradiasi sinar gamma untuk pengembangan klon unggul anggrek Spathoglottis plicata Blume. aksesi Bengkulu. Disertasi. Sekolah Pascasarjana. Institut Pertanian Bogor. Bogor.

Romeida, A., T. Hidayanti. 2005. Multiplikasi planlet anggrek Dendrobium cv. Thampomas $\mathrm{X}$ cv. Taq. Hawaii pada Beberapa Taraf Konsentrasi BAP dan Arang Aktif secara In Vitro. Laporan Penelitian (tidak dipublikasi).

Seeni, S., P.G. Latha. 1992. Foliar regeneration of endangered Red Vanda (Renanthera imschootiana Rolfe) Orchidase. Plant Cell. Tissue and Organ Culture. 29:167-172.

Seeni, S., P.G. Latha. 2000. In vitro multiplication and ecorehabilitation endangered Blue Vanda. Plant Cell. Tiss. Organ Cult. 61 : 1-8.

Sim, G.E., C.J. Goh, C.S. Loh. 2008. Induction of in vitro flowering in Dendrobium Madame Thong-In seedlings is assosiated with increase in endogenous N6-isopentenyl adenin (iP) dan N6- $\Delta 2$-isopentenyl-adenosin (iPA). Plant Cell Rep. 27:1281-1289.

Tee, C.S., M. Maziah, C.S. Tan. 2008. Induction of in vitro flowering in the orchid Dendrobium Sonia-17. Biol. Plant. 52(4): 723-726. 